\title{
Podmiotowość osoby i społeczeństwa jako wyzwanie dla edukacji obywatelskiej. Perspektywa Centesimus annus
}

\section{Uwagi wprowadzające}

Podstawę i inspirację dla niniejszych rozważań stanowi sformułowana w encyklice Centesimus annus teza, iż ,autentyczna demokracja możliwa jest tylko w państwie prawnym i w oparciu o poprawną koncepcję osoby ludzkiej. Wymaga ona spełnienia koniecznych warunków, jakich wymaga promocja zarówno poszczególnych osób, przez wychowanie i formację w duchu prawdziwych ideałów, jak i «podmiotowości» społeczeństwa, przez tworzenie struktur uczestnictwa oraz współodpowiedzialności"1. Słowa Jana Pawła II wskazują na potrzebę wychowania i formacji jednostek oraz promocji i rozwoju podmiotowości społeczeństwa w ramach struktur pośrednich. Ich istnienie i sprawne funkcjonowanie zagospodarowuje przestrzeń pomiędzy państwem i rynkiem, w której jednostka, wespół z innymi, może w pełni aktualizować swój osobowy potencjał. Oznacza to zarazem bycie i działanie zakotwiczone we właściwej definicji osoby, która, jak podkreśla autor encykliki, nie wyczerpuje się w byciu wytwórcą i nabywcą towarów ani też w byciu przedmiotem administracji państwowej. „Osoba ludzka żyje i "podmiotowość społeczeństwa» wzrasta wtedy, kiedy wiele różnych relacji wzajemnie się ze sobą splata”2. W społeczeństwie obywatelskim urzeczywistnia się dynamika międzyludzkiej koegzystencji oraz dobrowolnego, oddolnego i wielopoziomowego współdziałania osób i grup społecznych, które posiada wartość samą w sobie i właściwy sobie potencjał. Ono też, poprzez dialog, stanowi

\footnotetext{
CA 46.

2 CA 49.
} 
drogę poszukiwania i urzeczywistniania prawdy, w obecnych i przyszłych pokoleniach. Co więcej, temu właśnie wymiarowi życia indywidualnego i społecznego mają służyć, jak konkluduje papież, rynek i państwo.

U podstaw postulatu upodmiotowienia znajduje się, właściwe nauczaniu społecznemu Kościoła, a przywołane tu w sformułowaniu Wojciecha Chudego, założenie, że „człowiek w swojej niepowtarzalnej odrębności nie mógłby na własną rękę osiągnąć pewnego właściwego sobie dobra, dlatego musi włączyć się we współdziałanie, w uczestnictwo społeczne. Owe działania, specyficzne dla bytu ponadindywidualnego, muszą zostać zorganizowane, ponieważ dotyczą wielości osób o różnych temperamentach, wieku, inteligencji, a także ze względu na skomplikowanie samych działań, wymagają niekiedy wielu pośredników. Środkiem takim, o szczególnym walorze i randze społecznej, jest polityka”3.

Z powyższego wynika, że odpowiedzi na współczesne pytania o sposoby aktywizacji społecznej i obywatelskiej trzeba szukać u podstaw idei demokracji. Kwestia podmiotowości, którą w encyklice wydanej tuż po przełomie 1989 roku tak jednoznacznie wyeksplikował Jan Paweł II, należy do najważniejszych, gdyż to ona ma być fundamentem tworzenia struktur pośrednich w państwie demokratycznym, była kluczowym wyzwaniem po transformacji ustrojowej, osią budowania nowego porządku i współdziałania wszystkich aktorów, nie zaś (jedynie) zagospodarowywanie sfery pozarządowej i uruchamianie procesów wymiany dóbr, konkurowania idei i interesów. Podmiotowość aktorów indywidualnych i społecznych, w relacjach z państwem i rynkiem, stanowi w świetle tez Jana Pawła II probierz dobrze funkcjonującej demokracji.

To, co autor Centesimus annus określał jako upodmiotowienie osób i społeczności, współcześni socjologowie nazywają m.in. demokratyzacją życia społecznego. Polegać ma ona, jak to celnie ujmuje Paweł Poławski, na „zmniejszeniu dystansu między państwem a indywidualnymi obywatelami, zwiększaniu zaufania do instytucji formalnych czy zainteresowania tym, co "publiczne», i jednocześnie pogłębianiu przekonania o możliwości wpływania na bieg spraw publicznych [...]; chodzi o przekonanie obywateli, że każdy z nich jest partnerem formalnych instytucji życia zbiorowego i może mieć wpływ na ich funkcjonowanie. Chodzi także

3 W. Chudy, Osoba ludzka w społeczeństwie, w: Katolicka nauka społeczna. Podstawowe zagadnienia z życia społecznego i politycznego, red. S. Fel, J. Kupny, Katowice 2007, s. 31. 
o uaktywnienie tych, którzy się wcześniej w życie społeczne nie angażowali, a równocześnie o ograniczenie zjawiska tworzenia aktywnych elit" ${ }^{\text {, }}$ polegającego na mobilizowaniu osób już aktywnych, zmotywowanych i dysponujących odpowiednimi zasobami.

Omawiana teza Jana Pawła I nie straciła na sile i aktualności. Po ćwierćwieczu zmagań z rodzącą się demokracją i w ich niejako kontekście należy paradoksalnie do „rzeczy nowych”, wraz z pytaniem, jak osiągnąć zadowalający poziom owego upodmiotowienia. Problem wybrzmiewa szczególnie mocno w kontekście debaty o słabości społecznego i politycznego zaangażowania Polaków, o przyczynach społecznej absencji i strategiach aktywizacji, wreszcie o ograniczających zainteresowanie sprawami społecznymi zjawiskach indywidualizmu, konsumpcjonizmu, atrofii więzi społecznych. Kryterium tychże ocen jest stale aktualna wizja „obywatelskiej Polski”, jak piszą Kazimierz Frieske i Kinga Pawłowska: „społeczeństwa złożonego z ludzi cieszących się swoją podmiotowością i umiejących z niej korzystać, a też i traktowanych poważnie przez tworzone przez siebie publiczne instytucje [...]"5. Jest to zarazem powód, dla którego w debacie naukowej i praktyce pozarządowej pojawiło się w ostatnich kilkunastu latach żywe zainteresowanie edukacją obywatelską, jako kolejnym elementem namysłu nad pobudzeniem partycypacji społecznej w krajach europejskich.

Edukację obywatelską określa się często jako „szeroko pojęte kształcenie do aktywności obywatelskiej w sferze publicznej”' ${ }^{6}$ czy, jak pisze Agnieszka Łada, jako „działania mające na celu nabywanie przez obywateli zdolności i świadomości prawa do kształtowania wspólnoty politycz-

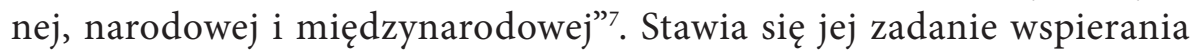
procesów socjalizacji w kierunku prospołeczności, poprzez przekaz wiedzy, nabywanie umiejętności i rozwój kompetencji społecznych. Zgodnie

4 P. Poławski, Technologie partycypacji, w: Partycypacja obywatelska. Od teorii do praktyki społecznej, red. A. Przybylska, A. Giza, Warszawa 2014, s. 30.

${ }_{5}$ K. W. Frieske, K. Pawłowska, Jeśli partycypacja - ... to z panna taka jak ty, w: Partycypacja obywatelska..., s. 19.

${ }_{6}$ K. Siellawa-Kolbowska, Edukacja obywatelska w Niemczech i Polsce jako problem badawczy, w: Edukacja obywatelska w Niemczech i Polsce. Raport z badań, red. K. Siellawa-Kolbowska, Warszawa 2008, s. 16.

7 A. Łada, Kształcenie obywatelskie w Polsce. Rola organizacji pozarządowych, „Trzeci Sektor" (2009), $\mathrm{nr}$ 17, s. 8. 
z Kartą Edukacji Obywatelskiej i Edukacji o Prawach Człowieka Rady Europy 2010 edukacja obywatelska oznacza „edukację, szkolenia, podnoszenie świadomości, informowanie oraz działania, których celem jest wyposażenie uczących się w wiedzę, umiejętności oraz kształtowanie ich postaw i zachowań mających wzmacniać realizację oraz obronę praw i obowiązków, poszanowanie różnorodności wraz z odgrywaniem aktywnej roli w społeczeństwie demokratycznym, przy jednoczesnym promowaniu i ochronie demokracji oraz rządów prawa" ${ }^{8}$. Obejmuje zatem teoretyczne przygotowanie i praktyczne wdrażanie do zaangażowania prospołecznego, nie zaś tylko, jak np. w przypadku edukacji politycznej, przysposobienie do działania w sferze polityki. Edukacja obywatelska przybiera postać kształcenia formalnego (np. szkoły), nieformalnego (np. organizacje pozarządowe) i pozaformalnego (proces uczenia się przez całe życie); może być kierowana do wszystkich grup wiekowych, zawodowych, społecznych'

Konkludując, dostrzegane przez socjologów, społeczników i polityków społecznych zapotrzebowanie na długofalową, zdefiniowaną i systematycznie realizowaną edukację obywatelską oraz pytanie o jej potencjalne funkcje w dążeniu do zwiększania podmiotowości społeczeństwa można zaliczyć do „rzeczy nowych”. Jednocześnie, jeśli rdzeniem demokracji jest podmiotowość osób i społeczności, a katalizatorem rozwoju wzajemne oddziaływanie jednostki i wspólnoty, to owa podmiotowość staje się zasadą i newralgicznym wyzwaniem dla edukacji obywatelskiej.

\section{Edukacja obywatelska jako wyzwanie}

Problem edukacji obywatelskiej, jak pisze Olga Napiontek, podnoszony jest w kontekście dyskusji nad kryzysem demokracji, „na który lekarstwem ma być demokratyzacja demokracji”"10. Chodzi między innymi

\footnotetext{
${ }^{8}$ Karta Edukacji Obywatelskiej i Edukacji o Prawach Człowieka Rady Europy 2010, s. 5; koncepcje i systemy edukacji obywatelskiej, które stają się przedmiotem polityki państw europejskich, są zależne od kontekstów środowiskowych, instytucjonalnych oraz historycznych, a także od adekwatnych sposobów rozumienia aktywności obywatelskiej.

${ }^{9}$ K. Siellawa-Kolbowska, Edukacja obywatelska w Niemczech $i$ Polsce jako problem badawczy, s. 18.

${ }^{10}$ O. Napiontek, Szkoła - przestrzeń obywatelskiego uczestnictwa, w: Edukacja obywatelska $w$ działaniu, red. A. Kordasiewicz, P. Sadura, Warszawa 2013, s. 106; na szereg zjawisk
} 
o poszerzenie rozumienia polityki, zwiększenie zainteresowania życiem społecznym, aktywniejszy udział w sferze publicznej, do czego potrzeba lepiej poinformowanych i wykształconych obywateli. Istotne jest również pogłębienie społecznej praxis, aby nie ograniczała się tylko do wspierania datkami stowarzyszeń i filantropii. Edukacja obywatelska ma stanowić remedium na deficyt zasobów kapitału społecznego, wśród których istotne miejsce zajmuje umiejętność i chęć współpracy. Innym argumentem podnoszonym w kontekście podkreślania roli edukacji obywatelskiej jest postrzeganie rodziny jako instytucji przeżywającej kryzys w zakresie przekazywania cnót obywatelskich i z tego powodu potrzebującej wsparcia ze strony wspólnoty. Wyjaśniając tę tezę, Napiontek pisze, iż „na fali indywidualizacji mamy do czynienia $\mathrm{z}$ dyferencjacją modeli wychowawczych, w ramach których przekazywane są różne wzorce i wartości. Zatem dużą rolę ma do odegrania kompleksowy projekt edukacji obywatelskiej, której zadaniem jest uwspólnianie reguł życia publicznego"11. I wreszcie za systematyczną i koncepcyjną refleksją nad modelami edukacji obywatelskiej przemawia coraz większy, a zarazem postulowany dostęp obywateli do zarządzania w sferze publicznej. Nakłada to na władze obowiązek włączania ich w procesy decyzyjne, poprzez udział w dyskusji, konsultacje społeczne, opiniowanie planowanych rozwiązań, udział w budowaniu strategii. W praktyce oznacza to wprowadzanie zasad demokracji partycypacyjnej, wymagającej szeregu kompetencji od jej uczestników ${ }^{12}$.

Inne typy argumentacji na rzecz edukacji obywatelskiej opisuje Jason Wood, który twierdzi, że w dwóch dominujących perspektywach traktuje się jednostkę jako nieposiadającą odpowiedniej wiedzy, wartości i niezbędnych cech przyszłego obywatela. W pierwszym przypadku mowa o deficycie demokracji, lokowanym jednakże na poziomie jednostkowych umiejętności zaangażowania się w rolę aktywnego obywatela. Drugie uzasadnienie odnosi się do zachowań ludzi młodych, uznawanych za nieprzygotowanych do dojrzałego obywatelstwa, potrzebujących

charakteryzujących współczesną kondycję społeczeństwa obywatelskiego wskazują również: M. Olejnik, P. Sadura i A. Urbanik, Społeczeństwo obywatelskie w budowie. Dylematy interwencji socjologicznej na przykładzie warsztatów dialogu społecznego, w: Partycypacja obywatelska..., s. 139-141.

${ }^{11}$ O. Napiontek, Szkoła - przestrzeń obywatelskiego uczestnictwa, s. 106-107.

12 Tamże, s. $10 \%$. 
kształtowania i uformowania, przekazu informacji na temat zobowiązań moralnych bardziej niż przygotowania do samodzielnego podejmowania decyzji ${ }^{13}$.

Z encykliki Centesimus annus można wywieść dwa sposoby uzasadnienia potrzeby edukacji obywatelskiej. W każdym z nich jej celem finalnym, a zarazem permanentnym jest podmiotowość osób i społeczności. Pierwsze uzasadnienie odwołuje się do personalistycznej antropologii wraz z koncepcją „osoby jako samodzielnego podmiotu decyzji moralnych, który podejmując je, tworzy porządek społeczny" ${ }^{14}$. Koncepcja ta implikuje potrzebę integralnego rozwoju osoby i społeczności. Rozwój jest nieodzowny, stanowi prawo i zobowiązanie, jest człowiekowi zadany. Pośród wielu dymensji znajduje się rozwój społecznej natury, który dokonuje się poprzez współdziałanie z innymi, realizujące rozmaite wartości osobowe i społeczne, autoteliczne i instrumentalne, kulminujące w realizacji wspólnego dobra. O potrzebie wychowania tej homogennej właściwości osoby, jaką jest „zdolność do uczestnictwa”, pisał Karol Wojtyła w dziele Osoba i czyn, twierdząc, iż „zdolność do uczestnictwa trzeba aktualizować, trzeba kształtować i wychowywać, aby dojrzała”" Wynika z powyższego, iż u podstaw edukacji obywatelskiej, jako procesu wspierającego rozwój integralny w określonym wymiarze, znajduje się troska o osobę, o poczucie przynależności do wspólnoty, o tożsamość obywatelską, wreszcie o świadomość sprawstwa w obszarze świata społecznego.

Druga ścieżka interpretacji edukacji obywatelskiej wiedzie od pojęć demokracji i społeczeństwa obywatelskiego i prowadzi do stwierdzenia, iż jego rdzeniem, tworzywem i racją istnienia jest dobrowolna aktywność osób i społeczności, zapełniająca sferę pomiędzy państwem a rynkiem i życiem prywatnym, podtrzymująca żywotność społeczności lokalnych, budująca wspólnotę i więzi społeczne, podejmująca wespół z państwem zadania polityki społecznej, realizująca na poziomie mikro- i makrospołecznym wyzwania solidarności i, jak pisał Benedykt xvi, urzeczywistniająca idee braterstwa i komunii ${ }^{16}$. Aktywność ta ucieleśnia się, jak

${ }^{13}$ J. Wood, Edukacja na rzecz efektywnego obywatelstwa, w: Edukacja obywatelska w działaniu, s. 135.

${ }^{14}$ CA 13.

${ }_{15}$ K. Wojtyła, Osoba i czyn oraz inne studia antropologiczne, Lublin 1994, s. 315.

${ }^{16}$ Benedykt XVI, Encyklika Caritas in veritate, 38. 
przypomina Jan Paweł II, w grupach pośrednich, „poczynając od rodziny, a kończąc na wspólnotach gospodarczych, społecznych, politycznych i kulturalnych, które jako przejaw tejże ludzkiej natury posiadają - zawsze w ramach dobra wspólnego - swą własną autonomię. To właśnie nazwałem - pisze papież - «podmiotowością» społeczeństwa, która wraz z podmiotowością jednostki została unicestwiona przez socjalizm realny" ${ }^{\prime 17}$. Jest to podmiotowość bliska rozumieniu republikańskiemu, wykraczająca poza definicję jurydycznie gwarantowanej aktywności wertykalnej w relacji z państwem. Jak pisze Kazimierz Dziubka, „republikańsko-obywatelski model samostanowienia urzeczywistnia się w ramach ról społecznych i politycznych, a nie poprzez dystansowanie się wobec nich. «Ja» obywatelskie jest zawsze «ja» zakotwiczonym albo «usytuowanym» w istniejących praktykach wspólnotowych oraz zawiązywanej wokół nich strukturze więzi emocjonalno-afektywnych"18.

W ciągu 25 lat od wydania Centesimus annus wypracowano i skorygowano warunki legislacyjne umożliwiające samoorganizację obywateli, funkcjonowanie trzeciego sektora, włączenie go w obręb polityki społecznej, świadczenie w jego obrębie usług społecznych. W świadomości społecznej utrwaliło się przekonanie o życiu w ustroju demokratycznym, jednakże różnie definiowano rolę aktywnego obywatelstwa, rozmaicie określano jego aksjologiczne podłoże, a naukowcy podkreślają, że wciąż aktualnym wyzwaniem pozostaje uzyskanie satysfakcjonującego poziomu zainteresowania i czynnego udziału w sprawach społecznych czy zgodność w interpretacji i stosowaniu reguł demokratycznych. Są to dla demokracji kwestie niezwykle istotne, na co wskazują chociażby stwierdzenia niemieckiego etyka społecznego, uważanego za prekursora edukacji politycznej w Niemczech, Bernharda Sutora, iż: „demokracja państwa prawa nie jest wyrazem społecznej anarchii, lecz wysoce skomplikowaną, a zarazem kruchą konstrukcją principiów, instytucji, reguł, praktyk, zwyczajów, która wymaga politycznej kultury, a więc także pielęgnacji ze strony obywateli”' ${ }^{19}$.

\footnotetext{
${ }^{17}$ CA 12.

${ }^{18}$ K. Dziubka, Obywatelskość jako virtù podmiotu demokracji, Wrocław 2008, s. 272.

19 B. Sutor, Etyka polityczna. Ujęcie całościowe na gruncie chrześcijańskiej nauki społecznej, Warszawa 1994, s. 37.
} 
W kontekście powyższych refleksji staje się jasne, że przygotowywanie do aktywności w społeczeństwie obywatelskim, zanurzonym we wspólnocie narodowej i państwowej, wymaga wsparcia: formalnego, nieformalnego, pozaformalnego ${ }^{20}$. Cel edukacji obywatelskiej sprowadza się do dynamicznej i stałej pomocy w budowaniu, umacnianiu, ożywianiu jedności tego, co indywidualne, $\mathrm{z}$ tym, co społeczne, w uzyskiwaniu coraz wyższego poziomu personalistycznego nastawienia wspólnot i prospołecznego nastawienia osób. Ideał ten trafnie opisał cytowany wyżej Sutor: „Im bardziej jednak wspólnoty w swoim zewnętrznym i wewnętrznym ładzie nastawiają się na personalność ich członków, tym mocniej te osoby wyrażają swoją indywidualność i wprzęgają ją w służbę wspólnoty [...]. Najpewniejszą, choć przy tym zawsze chwiejną podstawą ludzkiej wspólnoty jest wolny wybór jej członków, jako warunek zgody i porozumienia osób, które przyjmują lub tworzą porządkujące normy, budują instytucje i wyłaniają przywódców"21.

\section{Zasady podmiotowej edukacji obywatelskiej}

Zorientowana na wspieranie podmiotowości osób i społeczności edukacja obywatelska bazuje na aksjologii personalistycznej, ma charakter inkluzyjny, w założeniach jest obiektywna i wolna od ideologii, w zakresie koncepcji i treści jest wielowymiarowa i kompleksowa, w obszarze metod - partycypacyjna.

Aksjologicznym fundamentem edukacji obywatelskiej powinien być integralny rozwój osób oraz społeczności wraz z kluczowymi wartościami demokracji, do których zalicza się, jak pisze Jan Mazur: „1. Uznanie i poszanowanie wewnętrznej wartości i godności każdego człowieka; 2. Przekonanie o wartości zróżnicowania, rozmaitości i niepowtarzalności w obrębie społeczności ludzkiej; 3. Przyjęcie zasady pokonywania konfliktów, uwarunkowanych spotkaniem demokratycznych wartości

\footnotetext{
${ }^{20}$ Szczególną rolę przypisuje się edukacji obywatelskiej realizowanej poprzez i w ramach działan podmiotów pozarządowych; S. Nauman, Bildungsprozesse in bürgerschaftlichen Initiativen. Eine empirische Studie zur Transformation konjunktiver Orientierungen, Wiesbaden 2010.

${ }^{21}$ B. Sutor, Etyka polityczna. Ujęcie całościowe na gruncie chrześcijańskiej nauki społecznej, s. 198.
} 
(czyli takich, którym demokracja służy) z innymi wartościami”22. Kraje, które po 1989 roku reformują swoje systemy, winny zdaniem autora Centesimus annus zapewnić urzeczywistnianie „ideału demokratycznego” poprzez wyraźne uznanie praw człowieka ${ }^{23}$. Papież zwracał jednakże uwagę na sytuacje, w których mechanizmy demokratyczne działają wadliwie. Dzieje się tak w społeczeństwach, które „zatraciły zdolność podejmowania decyzji zgodnych $\mathrm{z}$ dobrem wspólnym"24. Źle funkcjonujące mechanizmy są więc konsekwencją odejścia od założeń antropologicznych i norm etycznych. Sprawiają, iż „postulaty społeczeństwa rozpatruje się nie przy użyciu kryteriów sprawiedliwości i moralności, ale raczej biorąc pod uwagę siłę wyborczą lub finansową stojących za nimi grup. Tego rodzaju odstępstwa od zasad moralności politycznej prowadzą z czasem do zniechęcenia i apatii, a w konsekwencji do zaniku zaangażowania politycznego i ducha obywatelskiego ludności, która czuje się poszkodowana i zawiedziona. Wynika stąd coraz większa niezdolność do włączania korzyści partykularnych w konsekwentny obraz dobra wspólnego [... ${ }^{\prime 25}$. Prowadzone przez ponad dwie minione dekady badania socjologiczne potwierdzają tę prawidłowość: między innymi wadliwe mechanizmy demokracji, słabość instytucji obywatelskich, brak wiedzy i zainteresowania upowszechnianiem wartości obywatelskich skutkują w polskim społeczeństwie apatią, obniżeniem poziomu zaufania do osób i instytucji, uniemożliwiają rozwój sprawstwa obywatelskiego ${ }^{26}$. Uwrażliwianie obecnych i przyszłych aktorów społeczeństwa obywatelskiego na potrzebę szacunku do współobywateli, do prawa i reguł demokratycznych, do zasad solidarności i dobra wspólnego należy do koniecznych elementów edukacji obywatelskiej.

${ }^{22}$ J. Mazur, Ad bonum per politicam. Wybrane zagadnienia z życia politycznego, Lublin 2011, S. 171.

${ }^{23}$ CA 47.

${ }^{24}$ Tamże.

${ }^{25}$ Tamże.

${ }^{26}$ G. Makowski, Czy spetnity się nasze sny? Wymarzony i realny pejzaż społeczeństw obywatelskich w Europie Srodkowo-Wschodniej, „Trzeci Sektor” (2012), nr 26, s. 31-47; A. Rymsza, Eksperci o kondycji sektora pozarządowego w Polsce w latach 2004-2011, „Trzeci Sektor” (2013), nr 30, s. 8-20; Aktywność Polaków w organizacjach obywatelskich, http://www.cbos. $\mathrm{pl} / \mathrm{pL} /$ publikacje/news/2016/o2/newsletter.php (8.03.2016). 
Papież ustosunkował się również do stale powracającej i współcześnie głoszonej tezy, iż demokracji odpowiada jedynie relatywizm moralny, i konkludował: „w sytuacji, w której nie istnieje żadna ostateczna prawda, będąca przewodnikiem dla działalności politycznej i nadająca jej kierunek, łatwo o instrumentalizację idei i przekonań dla celów, jakie stawia sobie władza. Historia uczy, że demokracja bez wartości łatwo się przemienia w jawny lub zakamuflowany totalitaryzm"27. Odpowiedzią na relatywistyczne koncepcje jest poszukiwanie konsensusu na bazie wartości podstawowych, nadrzędnych wobec interesów poszczególnych grup, a zarazem mających potencjał integracyjny. Chodzi o to, aby demokracja, jak argumentuje Jan Mazur, nie zamieniała się w narzędzie rynku i konkurencji, stojąc na straży interesów ekonomicznych poszczególnych grup społecznych ${ }^{28}$. Antidotum na minimalizm aksjologiczny są trzy filary demokracji: praworządność, solidarność i uczestnictwo ${ }^{29}$. Według Janusza Mariańskiego dla społecznego ładu, dla ochrony przed tyranią większości kluczowa jest koniunkcja demokracji z prawdą, z wartościami i z prawami człowieka ${ }^{30}$.

Aksjologicznie zorientowana edukacja obywatelska musi więc posiadać walor socjalizacyjny, umożliwiający internalizację wyżej wymienionych wartości $i^{31}$. W odpowiedzi na pytanie, czy porozumienie co do podstawowych wartości przekazywanych w procesie edukacji jest możliwe, Piotr Gliński wskazuje na obecne w polskiej kulturze wzorce, które mogą stanowić źródło konsensusu: wzór obywatela Marii Ossowskiej, dorobek Janusza Korczaka, idea praw człowieka, model prawa harcerskiego,

${ }^{27}$ CA 46.

${ }^{28}$ J. Mazur, Ad bonum per politicam..., s. 174 .

${ }^{29}$ Tamże, s. 181.

${ }^{30}$ J. Mariański, Demokracja bez wartości? Refleksje wokół encykliki „Centesimus annus” i sytuacji $w$ Polsce, w: Wartości u podstaw demokracji, red. J. Nagórny, A. Derdziuk of Mcap, Lublin 2002, s. 32-33.

${ }^{31}$ Według Bernharda Sutora „można [...], jak pokazują przykłady, pod szyldem demokracji koncentrować władzę, zamiast ją dzielić, monopolizować polityczną wolę narodu (jedna partia) zamiast podporządkować się konkurencji wolnych sił, w końcu próbować totalnie zintegrować społeczność, czyli poddać możliwie wiele społecznych procesów (od gospodarki po sztukę i religię) politycznej woli panujących. Demokracje można totalitarnie interpretować i praktykować, jeśli nie zwiąże się jej wyraźnie z dalszymi principiami i nie wyposaży w odpowiednie instytucje" (B. Sutor, Etyka polityczna. Ujęcie całościowe na gruncie chrześcijańskiej nauki społecznej, s. 199). 
wreszcie wartości chrześcijańskie, które „mogą stanowić naturalną, aksjologiczną podstawę proobywatelskiej reformy edukacyjnej" ${ }^{32}$.

Inkluzyjność edukacji obywatelskiej oznacza, iż obejmuje ona wszystkie grupy wiekowe, społeczne, zawodowe, również jednostki i środowiska narażone na marginalizację. Inkluzyjność zakłada orientację na włączanie każdego obywatela w proces pozyskiwania wiedzy, nabywania i rozwijania kompetencji społecznych, w budowanie relacji i więzi społecznych, jeśli te więzi uznaje się za podglebie obywatelskiej partycypacji: bardziej pierwotne i kluczowe niż zaufanie w świecie konkurencji i konsumizmu. To w obszarze tychże więzi tworzą się sieci wymiany i utrwalają reguły wzajemności ${ }^{33}$. Inkluzyjność edukacji obywatelskiej pozwala ograniczyć sfery deficytów strukturalnego zorganizowania społeczeństwa, wyjść naprzeciw środowiskom i osobom, które z różnych powodów nie istnieją w przestrzeni publicznej, brak im czy to zasobów finansowych, wiedzy, kompetencji, czy inicjatorów, którzy mogliby pośredniczyć w samoorganizacji bądź ją animować. Joachim Wiemeyer pisze, że kwestie te są obszarem możliwego zaangażowania chrześcijan ${ }^{34}$.

Inkluzyjna edukacja obywatelska może oddziaływać prewencyjnie, chronić przed stopniowym wyłączaniem się z kontaktów społecznych osoby balansujące na granicy wykluczenia. Inkluzyjność odpowiada sformułowanemu przez autora Centesimus annus postulatowi budowania kultury, która „pomnaża wiarę w ludzkie możliwości człowieka ubogiego, a zatem w zdolność do polepszenia własnej sytuacji przez pracę, to jest przez pozytywny wkład w dobrobyt gospodarczy" ${ }^{35}$. Tak ujmowana edukacja obywatelska realizować się może poprzez komplementarne oddziaływanie szkół, uczelni, uniwersytetów trzeciego wieku, organizacji pozarządowych, parafii, lokalnych domów kultury, czyli zarówno instytucji powołanych do tego bezpośrednio, jak i realizujących cele edukacji obywatelskiej poza ramami działalności statutowej.

${ }^{32}$ P. Gliński, Demokracja bez partycypacji. O konieczności zaangażowania obywatelskiego uczniów, w: Wychowanie. Pojęcia. Procesy. Konteksty, t. 4, red. M. Dudzikowa, M. Czerepaniak-Walczak, Gdańsk 2008, s. 193.

${ }^{33}$ K. W. Frieske, K. Pawłowska, Jeśli partycypacja - ... to z panna taka jak ty, s. 19.

${ }^{34} \mathrm{~J}$. Wiemeyer, Zaangażowanie polityczne chrześcijan w partiach politycznych $i$ wolnych stowarzyszeniach, w: Katolicka nauka społeczna. Podstawowe zagadnienia z życia społecznego i politycznego, s. 222-223.

${ }^{35}$ CA 51. 
Przyjęcie zasady inkluzyjności w edukacji obywatelskiej uwzględnia ustalenia socjologiczne wskazujące na problem nierówności w zasobach kapitału społecznego i kulturowego, predysponujących do zaangażowania społecznego bądź wyłączających ze względu na zbyt niski ich poziom. Nie może umknąć uwadze fakt, iż poza zasobami takimi, jak wykształcenie, wysokość dochodów i pozycja zawodowa, na partycypację obywatelską wpływają takie „zasoby polityczne”, jak możliwość dysponowania czasem i środkami finansowymi oraz umiejętności komunikacyjne i organizacyjne. Oznacza to konieczność ograniczania - w sferze politycznej i obywatelskiej - konsekwencji zróżnicowania społecznego i dążenie do tego, aby korzyści z partycypacji społecznej nie wzmacniały procesów wykluczenia społecznego, aby procesy deliberacji nie działały na korzyść grup dominujących, jako tych, które dzięki zasobom mają do niej dostęp. Według Pawła Poławskiego ciekawym rozwiązaniem praktycznym jest realizacja idei „demokracji oddolnej, zakładająca osadzenie procesów decyzyjnych w społecznościach lokalnych z pominięciem demokracji reprezentacyjnej i związanie mechanizmów partycypacyjnych ze (zróżnicowaną z założenia) strukturą lokalnej społeczności" ${ }^{36}$. Badania socjologiczne w samorządach UsA pokazują, że „pozycja na rozmaitych wiecach i zebraniach niekoniecznie pokrywa się z pozycją społeczną mierzoną standardowymi wskaźnikami statusu [...], co oznacza, że pozycja i znaczenie jednostek w ramach społeczności nie muszą mieć związku z zamożnością, wykształceniem czy wykonywanym zawodem" ${ }^{37}$.

Edukacja obywatelska winna być wielowymiarowa i kompleksowa: przekazywać i upowszechniać wiedzę całościową i aktualną, dotyczącą modelowych rozwiązań i doświadczeń, w zakresie m.in. podstaw funkcjonowania państwa, etyki życia społecznego, praw i obowiązków obywatelskich, zasad uczestnictwa w debacie publicznej, zadań i prerogatyw instytucji obywatelskich, narzędzi pozostających w gestii obywateli w skali mikro- i makrospołecznej, roli mediów itp. ${ }^{38}$ Postulat ten, w kontekście

${ }^{36}$ P. Poławski, Technologie partycypacji, w: Partycypacja obywatelska..., s. 33.

37 Tamże.

${ }^{38} \mathrm{~W}$ ogólnokrajowych programach kształcenia w systemach edukacyjnych w Europie wymienia się takie zagadnienia, jak: system społeczno-polityczny kraju, prawa człowieka, wartości demokratyczne, różnorodność kulturowa, równość i sprawiedliwość, tolerancja i dyskryminacja, zrównoważony rozwój, przynależność i tożsamość narodowa i europejska, historia, kultura i literatura Europy, funkcjonowanie instytucji i perspektywa Unii 
sugestii Jana Pawła II, dotyczy również jednoczesnego z transferem wiedzy promowania postaw i wartości będących fundamentem demokracji, a także tzw. cnót obywatelskich.

W dyskusjach naukowców pojawia się dylemat: „ile wiedzy a ile praktyki?”, czy w innym wariancie: „wiedza czy praktyka?”. Zdaniem Krzysztofa Koseły daje się go rozwiązać poprzez wprowadzenie zmiennych czasu i miejsca, a także rodzaju wiedzy. Czas nauki szkolnej jest zatem okresem przede wszystkim pozyskiwania wielorakiej wiedzy, w tym obywatelskiej, oraz praktykowania działań samorządnych, wspólnych i prospołecznych na terenie szkoły, niekoniecznie zaś poza nią ${ }^{39}$. Pogodzenie tych dwóch obszarów jest łatwiejsze na etapie kształcenia uniwersyteckiego i poprzez oddziaływanie uniwersytetu jako instytucji naukowej i kulturowej. Jako „odwzorowanie w mikroskali społeczeństwa obywatelskiego" uniwersytet stanowi, używając sformułowania Jerzego Węcławskiego, „znakomitą podstawę do kształtowania postaw obywatelskich"40. Jednakże niezależnie od wieku adresatów i form kształcenia proces edukacji obywatelskiej ma szansę i powinien przebiegać na wielu poziomach. Edukacyjnie oddziałują postawy i wzorce osobowe, poziom kultury politycznej i debaty medialnej, funkcjonowanie instytucji państwowych i samorządowych. Kompleksowość oznacza zatem dbałość o spójność przekazu i praktyki społecznej różnych podmiotów, o wysokie standardy etyczne w ich działaniach.

Istotnym wymogiem w edukacji obywatelskiej jest zasada partycypacji. Proces edukacyjny winien udostępniać i umożliwiać trening reguł funkcjonowania w demokratycznym państwie prawa, stosowanie norm etycznych obowiązujących uczestników dyskursu publicznego, zdobywanie

Europejskiej, stosunki międzynarodowe, funkcjonowanie organizacji międzynarodowych; zob. Edukacja obywatelska w Europie, Warszawa 2012; por. także: F. Reheis, Politische Bildung. Eine kritische Einführung, Wiesbaden 2014.

${ }^{39}$ Wyniki badań międzynarodowych dowodzą, że „tym lepsze wyniki osiągają uczniowie $\mathrm{w}$ testach wiedzy obywatelskiej, im częściej angażują się w różne formy aktywności wewnątrzszkolnej, tj. biorą udział w pracach szkolnego samorządu i w wyborach do niego, zabierają głos w dyskusjach i w podejmowaniu decyzji dotyczących szkoły, aktywnie działają w szkolnych zespołach muzycznych i teatralnych" (K. Koseła, Nauka szkolna i działanie obywatelskie, w: Edukacja obywatelska $w$ działaniu, s. 101).

${ }^{40} \mathrm{~J}$. Węcławski, Współczesny uniwersytet a społeczeństwo obywatelskie, w: Rola uczelni w rozwijaniu społeczeństwa obywatelskiego, red. J. Dietl, Z. Sapijaszka, Łódź 20o9, s. 82. 
i gromadzenie pozytywnych doświadczeń: bycia włączonym, przynależności do wspólnoty, współdziałania w zakresie definiowania celów, wyznaczania strategii i realizacji zadań, przyjmowania odpowiedzialności, uczestnictwa w efektach wspólnych przedsięwzięć oraz ich ewaluacji. Nauka poprzez praxis jest jednym $\mathrm{z}$ istotnych faktorów edukacji obywatelskiej, zatem do jej kluczowych celów należy stwarzanie warunków dla tej praktyki ${ }^{41}$, czy to $\mathrm{w}$ systemie edukacji formalnej, czy w edukacyjnej działalności organizacji pozarządowych lub poprzez ich codzienną działalność.

Obiektywizm edukacji obywatelskiej przejawia się przede wszystkim w tym, iż jest wolna od ideologii, co zakłada wspieranie rozwoju osób i społeczności w omawianym obszarze, niezależnie od mapy politycznej i bez prawa do narzucania ideologicznych narracji. Wśród współczesnych zagrożeń obiektywizmu znajduje się, sygnalizowane w kontekście edukacji obywatelskiej m.in. przez Marka Rymszę, zjawisko tzw. poprawności politycznej i związanego z nią konformizmu oraz podwójnych standardów w życiu publicznym ${ }^{42}$. Edukacja obywatelska podporządkowana bieżącym interesom ugrupowań politycznych czy aktualnie propagowanych ideologii stoi w sprzeczności z założeniem o upodmiotowieniu, w które wpisana jest wolność osób, prawo do samodzielnego określania i głoszenia poglądów, dobrowolność aktywności prospołecznej i jej motywów, szacunek dla autonomii i praw innych aktorów życia społecznego oraz reguł demokratycznych.

\section{Podsumowanie}

Uwzględnienie powyższych zasad zmierza do tego, iż edukacja obywatelska może przyczyniać się do podnoszenia poziomu świadomości obywatelskiej, wzrostu poczucia sprawstwa i przekonania, że wraz z innymi można wpływać na sprawy całego kraju, a zarazem chroni przed instrumentalnym wykorzystywaniem aktywności obywateli, umacnia

${ }^{41}$ Przykładem mogą być propozycje dydaktyczne sformułowane w podręczniku pod redakcją Wolfganga Sandera Politische Bildung, Schwalbach 2014, s. 241-292; znajdują się wśród nich: nauka ukierunkowana na adresata, analiza kazusów, rozwiązywanie problemów, debata w kontekście kontrowersyjnym, orientacja na działanie.

${ }^{42}$ M. Rymsza, Edukacja obywatelska w systemie demokratycznym, „Trzeci Sektor” (2009), nr 17, s. 5 . 
ich więź z państwem i społecznością lokalną, jest kolejnym ogniwem w procesie aktywizacji społecznej, umacnia mechanizmy demokratyczne.

Personalistyczny fundament oraz uruchamianie wrażliwości na dobro wspólne, dowartościowanie postaw szacunku dla współobywateli, promowanie postaw obywatelskich stanowi wkład w umacnianie etycznego fundamentu społeczeństwa obywatelskiego. Długofalowe udostępnianie wieloaspektowej wiedzy oraz umożliwienie nabywania umiejętności i kompetencji społecznych możliwie szerokiemu gronu odbiorców oznacza uznanie, że w każdym czasie i w każdych okolicznościach mają oni posiadać przygotowanie i legitymizację do skutecznego udziału w debacie publicznej, w dialogu obywatelskim, we współtworzeniu dobra wspólnego. Dążenie do obiektywizmu w edukacji obywatelskiej zakłada, że adresaci mają przed sobą wolny wybór w zakresie poglądów politycznych, sposobów, miejsc i form praktykowania obywatelskości, w zależności od posiadanych zasobów i planów życiowych. Kompleksowość treści, metod i form oddziaływania wiąże się z podążaniem za diagnozami aktywności obywatelskiej oraz lokalnych problemów społecznych, za potrzebami różnych grup, za wyzwaniami polityki społecznej.

Wspieranie podmiotowości osób i społeczności w procesie edukacji obywatelskiej jest gwarantem, iż spełni ona ważne funkcje społeczne: od poznawczej, rozwojowej i readaptacyjnej po integracyjną i aktywizacyjną. Stanowi wyzwanie nie tylko dla osób tworzących koncepcje i metody nauczania, lecz także dla decydujących o jej kształcie w danym czasie, miejscu, w konkretnych uwarunkowaniach społecznych i politycznych. Kompetentny, światły obywatel ustroju demokratycznego staje się bowiem pełnoprawnym, wymagającym partnerem, inicjatorem i podmiotem zmian. Jednakże ten kierunek rozwoju demokracji niesie ze sobą, jak można wnosić z lektury Centesimus annus, ogromny potencjał integralnego rozwoju.

\section{Bibliografia}

Aktywność Polaków w organizacjach obywatelskich, http://www.cbos.pl/PL/publikacje/news/2016/o2/newsletter.php (8.03.2016).

Benedykt Xvi, Encyklika Caritas in veritate, przedruk: Libreria Editrice Vaticana, Wydawnictwo M, Kraków 2009. 
Chudy W., Osoba ludzka w społeczeństwie, w: Katolicka nauka społeczna. Podstawowe zagadnienia z życia społecznego i politycznego, red. S. Fel, J. Kupny, Księgarnia św. Jacka, Katowice 2007, s. 31-56.

Dziubka K., Obywatelskość jako virtù podmiotu demokracji, Wydawnictwo Uniwersytetu Wrocławskiego, Wrocław 2008.

Edukacja obywatelska w Europie, Fundacja Rozwoju Systemu Edukacji, Warszawa 2012.

Frieske K. W., Pawłowska K., Jeśli partycypacja - ... to z panna taka jak ty, w: Partycypacja obywatelska. Od teorii do praktyki społecznej, red. A. Przybylska, A. Giza, Wydawnictwo Naukowe Scholar, Warszawa 2014, s. 1226.

Gliński P., Demokracja bez partycypacji. O konieczności zaangażowania obywatelskiego uczniów, w: Wychowanie. Pojęcia. Procesy. Konteksty, t. 4, red. M. Dudzikowa, M. Czerepaniak-Walczak, Gdańskie Wydawnictwo Psychologiczne, Gdańsk 2008, s. 173-203.

Jan Paweł II, Encyklika Centesimus annus, przedruk: Libreria Editrice Vaticana, Włocławek 1991.

Karta Edukacji Obywatelskiej i Edukacji o Prawach Człowieka Rady Europy 2010, https://rm.coe.int/CoERmpublicCommonSearchServices/Displaydctmcontent?documentId=09000016804884ce (11.03.2016).

Koseła K., Nauka szkolna i działanie obywatelskie, w: Edukacja obywatelska $w$ działaniu, red. A. Kordasiewicz, P. Sadura, Wydawnictwo Naukowe Scholar, Warszawa 2013.

Łada A., Kształcenie obywatelskie w Polsce. Rola organizacji pozarzadowych, „Trzeci Sektor” (2009), nr 17, s. 8-14.

Makowski G., Czy spełnily się nasze sny? Wymarzony i realny pejzaż społeczeństw obywatelskich w Europie Środkowo-Wschodniej, „Trzeci Sektor” (2012), nr 26, s. 31-47.

Mariański J., Demokracja bez wartości? Refleksje wokół encykliki „Centesimus annus" i sytuacji w Polsce, w: Wartości u podstaw demokracji, red. J. Nagórny, A. Derdziuk ofmcap, Wydawnictwo Diecezjalne w Sandomierzu, Lublin 2002, s. 29-71.

Mazur J., Ad bonum per politicam. Wybrane zagadnienia $z$ życia politycznego, Wydawnictwo KUL, Lublin 2011.

Napiontek O., Szkoła - przestrzeń obywatelskiego uczestnictwa, w: Edukacja obywatelska $w$ działaniu, red. A. Kordasiewicz, P. Sadura, Wydawnictwo Naukowe Scholar, Warszawa 2013, s. 104-127. 
Nauman S., Bildungsprozesse in bürgerschaftlichen Initiativen. Eine empirische Studie zur Transformation konjunktiver Orientierungen, vs Verlag für Sozialwissenschaften, Wiesbaden 2010.

Olejnik M., Sadura P., Urbanik A., Społeczeństwo obywatelskie w budowie. Dylematy interwencji socjologicznej na przykładzie warsztatów dialogu społecznego, w: Partycypacja obywatelska. Od teorii do praktyki społecznej, red. A. Przybylska, A. Giza, Wydawnictwo Naukowe Scholar, Warszawa 2014, s. $138-156$.

Politische Bildung, Hg. W. Sander, Wochenschau Verlag, Schwalbach 2014.

Poławski P., Technologie partycypacji, w: Partycypacja obywatelska. Od teorii do praktyki społecznej, red. A. Przybylska, A. Giza, Wydawnictwo Naukowe Scholar, Warszawa 2014, s. 27-41.

Reheis F., Politische Bildung. Eine kritische Einführung, vs Verlag für Sozialwissenschaften, Wiesbaden 2014.

Rymsza A., Eksperci o kondycji sektora pozarządowego w Polsce w latach 20042011, „Trzeci Sektor” (2013), nr 30, s. 8-20.

Rymsza M., Edukacja obywatelska w systemie demokratycznym, „Trzeci Sektor” (2009), nr 17, s. 2-7.

Siellawa-Kolbowska K., Edukacja obywatelska w Niemczech i Polsce jako problem badawczy, w: Edukacja obywatelska $w$ Niemczech i Polsce. Raport z badań, red. K. Siellawa-Kolbowska, Instytut Spraw Publicznych - Fundacja Konrada Adenauera w Polsce, Warszawa 2008, s. 13-23.

Sutor B., Etyka polityczna. Ujęcie całościowe na gruncie chrześcijańskiej nauki społecznej, Wydawnictwo Fundacji Aтк, Warszawa 1994.

Węcławski J., Współczesny uniwersytet a społeczeństwo obywatelskie, w: Rola uczelni w rozwijaniu społeczeństwa obywatelskiego, red. J. Dietl, Z. Sapijaszka, Fundacja Edukacyjna Przedsiębiorczości, Łódź 2009, s. 79-85.

Wiemeyer J., Zaangażowanie polityczne chrześcijan w partiach politycznych $i$ wolnych stowarzyszeniach, w: Katolicka nauka społeczna. Podstawowe zagadnienia z życia społecznego i politycznego, red. S. Fel, J. Kupny, tłum. S. Fel, Księgarnia św. Jacka, Katowice 2007, s. 205-225.

Wojtyła K., Osoba i czyn oraz inne studia antropologiczne, Towarzystwo Naukowe KUL, Lublin 1994.

Wood J., Edukacja na rzecz efektywnego obywatelstwa, w: Edukacja obywatelska $w$ działaniu, red. A. Kordasiewicz, P. Sadura, tłum. A. Sekuła, Wydawnictwo Naukowe Scholar, Warszawa 2013, s. 128-144. 


\begin{abstract}
Abstrakt
W encyklice Centesimus annus Jan Paweł II stwierdza, iż do istotnych zadań związanych z budowaniem demokracji należy dążenie do upodmiotowienia osób i społeczności. Po 25 latach postulat ten pozostaje aktualny wraz z pytaniem, jak osiągnąć wysoki poziom owego upodmiotowienia, jak rozwijać tożsamość społeczną i obywatelską, podnosić wśród obywateli poczucie sprawstwa, wzmacniać ich gotowość do działań prospołecznych i aktywności w sferze publicznej. Papież wskazuje, że ma temu służyć formacja i wychowanie jednostek oraz promocja i rozwijanie zaangażowania obywateli w strukturach pośrednich. Są to zarazem zadania stawiane obecnie edukacji obywatelskiej. Celem tekstu jest ukazanie kluczowego dla demokracji postulatu upodmiotowienia jako zadania i zasady edukacji obywatelskiej w kontekście encykliki Centesimus annus.
\end{abstract}

Subjectivity person and society as a challenge for civic education. The prospect of Centesimus annus

\begin{abstract}
In his encyclical Centesimus annus, John Paul II states that striving to empower people and society is one of the essential assignments related to building a democracy. After 25 years, this postulate is still current, along with the question concerning obtaining a high level of empowerment, as well as how to develop social and civil identity, raising citizens' sense of agency, and strengthening their willingness to do pro-social activities and become active in the public sphere. The Pope points out that this is to help form and educate individuals so as to promote and develop citizenship involvement in intermediate structures. These are the tasks presently set for civic education. The purpose of the text is to present the key democratic postulate of empowerment as the task and principle of civic education in the context of the encyclical Centesimus annus.
\end{abstract}

